\title{
Akimiski Island, Nunavut, Canada: The Use of Cree Oral History and Sea-Level Retrodiction to Resolve Aboriginal Title
}

\author{
Leonard J.S. Tsuji, ${ }^{1}$ Zachariah General, ${ }^{2}$ Stephen R.J. Tsuji, ${ }^{3}$ Evelyn Powell, ${ }^{4}$ Konstantin Latychev, ${ }^{4}$ \\ Jorie Clark ${ }^{5}$ and Jerry X. Mitrovica ${ }^{4}$
}

(Received 8 August 2019; accepted in revised form 17 June 2020)

\begin{abstract}
On 1 April 1999, Akimiski Island of the western James Bay region of northern Ontario, Canada, was included in the newly formed territory of Nunavut, Canada — an Inuit-dominated territory—even though the Inuit had never asserted Aboriginal title to the island. By contrast, the Omushkegowuk Cree of the western James Bay region have asserted Aboriginal title to Akimiski Island. The Government of Canada by their action (or inaction) has reversed the onus of responsibility for proof of Aboriginal title from the Inuit to the Cree. In other words, the Government of Canada did not follow their own guidelines and the common-law test for proof of Aboriginal title. In this paper, we documented and employed Cree oral history as well as a sea-level retrodiction (based on state-of-the-art numerical modeling of past sea-level changes in James Bay), which incorporated a modified ICE-6G ice history and a 3-D model of Earth structure, to establish that criterion 2 of the test for Aboriginal title has now been fully met. In other words, Cree traditional use and occupancy of Akimiski Island was considered sufficiently factual at the time of assertion of sovereignty by European nations. As all the criteria of the common-law test for proof of Aboriginal title in Canada, with respect to Akimiski Island, have now been addressed, the Cree have sufficient basis to initiate the process of a formal land claim.
\end{abstract}

Key words: Aboriginal title; Akimiski Island; Cree oral history; Indigenous knowledge; post-glacial isostatic adjustment; sea-level change modelling

RÉSUMÉ. Le 1 1er avril 1999, l'île Akimiski, située dans la région ouest de la baie James, dans le nord de l’Ontario, au Canada, a été intégrée au nouveau territoire du Nunavut, territoire dominé par les Inuits, même si ceux-ci n'avaient jamais revendiqué le titre ancestral de cette île. En revanche, les Cris omushkegowuk de la région ouest de la baie James ont revendiqué leur titre ancestral à l'égard de l'île Akimiski. Le geste (ou l'absence de geste) du gouvernement du Canada a eu pour effet d'inverser la responsabilité de prouver le titre ancestral des Inuits aux Cris. Autrement dit, le gouvernement du Canada n'a pas respecté ses propres directives et les critères de droit commun comme preuve de titre ancestral. Dans cet article, nous avons documenté et employé l'histoire orale crie ainsi qu'une rétrodiction du niveau de la mer (d'après une modélisation numérique perfectionnée d'anciens changements du niveau de la mer de la baie James), contenant un historique modifié de la glace ICE-6G et une modélisation en trois dimensions de la structure de la Terre, afin d'établir que le critère 2 des critères du titre ancestral est maintenant entièrement atteint. Autrement dit, l'usage et l'occupation traditionnels de l'île Akimiski par les Cris ont été considérés comme des faits suffisants au moment de la revendication de la souveraineté par les nations européennes. Puisque tous les critères de droit commun permettant de prouver le titre ancestral de l'île Akimiski au Canada ont maintenant été respectés, les Cris disposent de fondements suffisants pour entreprendre une revendication territoriale officielle.

Mots clés : titre ancestral; île Akimiski; histoire orale crie; connaissances autochtones; compensation isostatique postglaciaire; modélisation du changement du niveau de la mer

Traduit pour la revue Arctic par Nicole Giguère.

\footnotetext{
${ }^{1}$ Corresponding author: Department of Physical and Environmental Sciences, University of Toronto, 1265 Military Trail, Toronto, Ontario M1C 1A4, Canada; leonard.tsuji@utoronto.ca

${ }^{2}$ Chiefs of Ontario, 468 Queen Street East, Suite 400, Toronto, Ontario M5A 1T7, Canada

${ }^{3}$ University of Waterloo, School of Environment, Resources and Sustainability, University of Waterloo, 200 University Avenue West, Waterloo, Ontario N2L 3G1, Canada

${ }^{4}$ Harvard University, Department of Earth and Planetary Sciences, Harvard University, 20 Oxford Street, Cambridge, Massachusetts 02138, USA

${ }^{5}$ Oregon State, College of Earth, Ocean, and Atmospheric Sciences, Oregon State University, 101 Southwest 26th Street, Corvallis, Oregon 97331, USA

(C) The Arctic Institute of North America
} 


\section{INTRODUCTION}

Present-day Canada was created through land acquisitions. When the Dominion of Canada was formed in 1867, only the provinces of Ontario, Quebec, New Brunswick, and Nova Scotia were included in the boundaries of the new country, and the provinces of Quebec and Ontario were only a fraction of their present size (Fig. 1). In 1870, Rupert's Land and the North-Western Territory would be acquired by the Dominion of Canada through an Imperial (British) Order-in-Council; these lands would be amalgamated to form the Northwest Territories (Figs. 1 and 2) (Cauchon and Cockburn, 1867; Rupert's Land and North-Western Territory - Enactment No. 3, 1870). Furthermore, the Canadian government would have to compensate "Indians," as it was recognized that Indians had claims to these lands (Cauchon and Cockburn, 1867; Rupert's Land and North-Western Territory - Enactment No. 3, 1870). Previously, the British Crown had recognized Indians' rights to land in North America through the Royal Proclamation of 1763 (INAC, 2016). This document asserted that Indian lands had to be acquired through consent (i.e., ceded or purchased; INAC, 2016). From 1870 to 1999 , the Northwest Territories was partitioned into new provinces and territories; moreover, the boundaries of several of the existing provinces were extended (Fig. 3; AANDC, 2019). In keeping with Indian land rights in North America, treaties between the Government of Canada and Indian groups had to be signed (AANDC, 2019).

Although the Ojibwa and James Bay Cree of northern Ontario signed Treaty No. 9 in 1905-06 and the adhesions to the treaty in 1929-30, there was no mention of the western James Bay marine islands (Treaty No. 9, 1905-06; Fig. 4). The western James Bay Cree (or Omushkego Cree) of northern Ontario have realized the importance of the absence of marine islands from Treaty No. 9 and the adhesions, and they maintain that they have never relinquished their claim to Akimiski Island (and the other western James Bay marine islands) through treaty or any other means (Parliament of Canada, 1999). Nonetheless, on 1 April 1999, "the islands in Hudson Bay, James Bay [which includes Akimiski Island] and Ungava Bay that [were] not within Manitoba, Ontario or Quebec" were included in the newly established, Inuit-dominated territory of Nunavut, Canada (Nunavut Act, 1993: c.28, Part 1, 3(b)) even though the Inuit never asserted Aboriginal title (i.e., land rights to resources, such as, water, timber, and minerals) to the western James Bay islands, including Akimiski Island (Nunavut Land Claims Agreement, 1993).

Herein lies the problem - two Canadian Indigenous groups lay claim to Akimiski Island: the Inuit through the Nunavut Act (1993) and the western James Bay Cree through Aboriginal title. However, this dispute can be settled, because a test of Aboriginal title exists in Canada (Denhez, 1982; Delgamuukw v. British Columbia, 1997; Hurley, 2000; also refer to Tsilhqot'in Nation v. British Columbia, 2014). The common-law test for proof of
Aboriginal title is as follows:

1. The Aboriginal group is, and was, an organized society.

2. The organized society has occupied the specific territory over which it asserts Aboriginal title since time immemorial. The traditional use and occupancy of the territory must have been sufficient to be an established fact at the time of assertion of sovereignty by European nations.

3. The occupation of the territory by the Aboriginal group was largely to the exclusion of other organized societies.

4. The Aboriginal group can demonstrate some continuing current use and occupancy of the land for traditional purposes.

5. The group's Aboriginal title and rights to resource use have not been dealt with by treaty.

6. Aboriginal title has not been eliminated by other lawful means (INAC, 1993:5-6, 2003:8).

Pritchard et al. (2010) found no evidence (published or online) in the academic databases, grey literature, and published Inuit oral history that supports Inuit title to Akimiski Island, specifically, with reference to the 2nd and 4th criteria of the test of Aboriginal title. In fact, the Inuit Land Use and Occupancy Project (Milton Freeman Research Limited, 1976), a comprehensive record of Inuit land use in the Northwest Territories, Canada, did not refer to historical or present Inuit land use or occupation of Akimiski Island. This work is the authoritative Inuit land use and occupancy record and was the basis for the Inuit land claim that resulted in the formation of the territory of Nunavut in Canada. Indeed, in the Nunavut Land Claims Agreement (1993), beginning in Article 3.1.1 of this document, it states that the "Nunavut Settlement Area shall be composed of 'Area A'... and 'Area B', being the Belcher Islands, associated islands and adjacent marine areas in Hudson Bay, described in Part 3 [Area B: section 3.3.1; p. 17]". Marcopeet, King George, Salliquit, and Belcher Islands were all mentioned (p. 19-20), but Akimiski Island was not named. Further, in Schedule 3-1, the Nunavut Settlement Area map (section 3.4.1) does not include Akimiski Island within Area B (the southernmost area of Nunavut; p. 21); however, a disclaimer appears that states "for general information purposes only" (p. 21). In Schedule 9-1, Existing Conservation Areas (Section 9.1.1, Part 1:83), migratory bird sanctuaries within the Nunavut Settlement Area were listed; eight bird sanctuaries were named, but the Akimiski Island Bird Sanctuary was not among them.

By contrast, General et al. (2017), using published and on-line evidence retrieved from the academic databases, grey literature and published Cree oral history, showed that all criteria of the common-law test of Aboriginal title were met to support Cree title to Akimiski Island; however, the written record only alluded to the Cree using Akimiski Island prior to European contact. Thus, traditional use and occupancy of Akimiski Island could only be definitively 


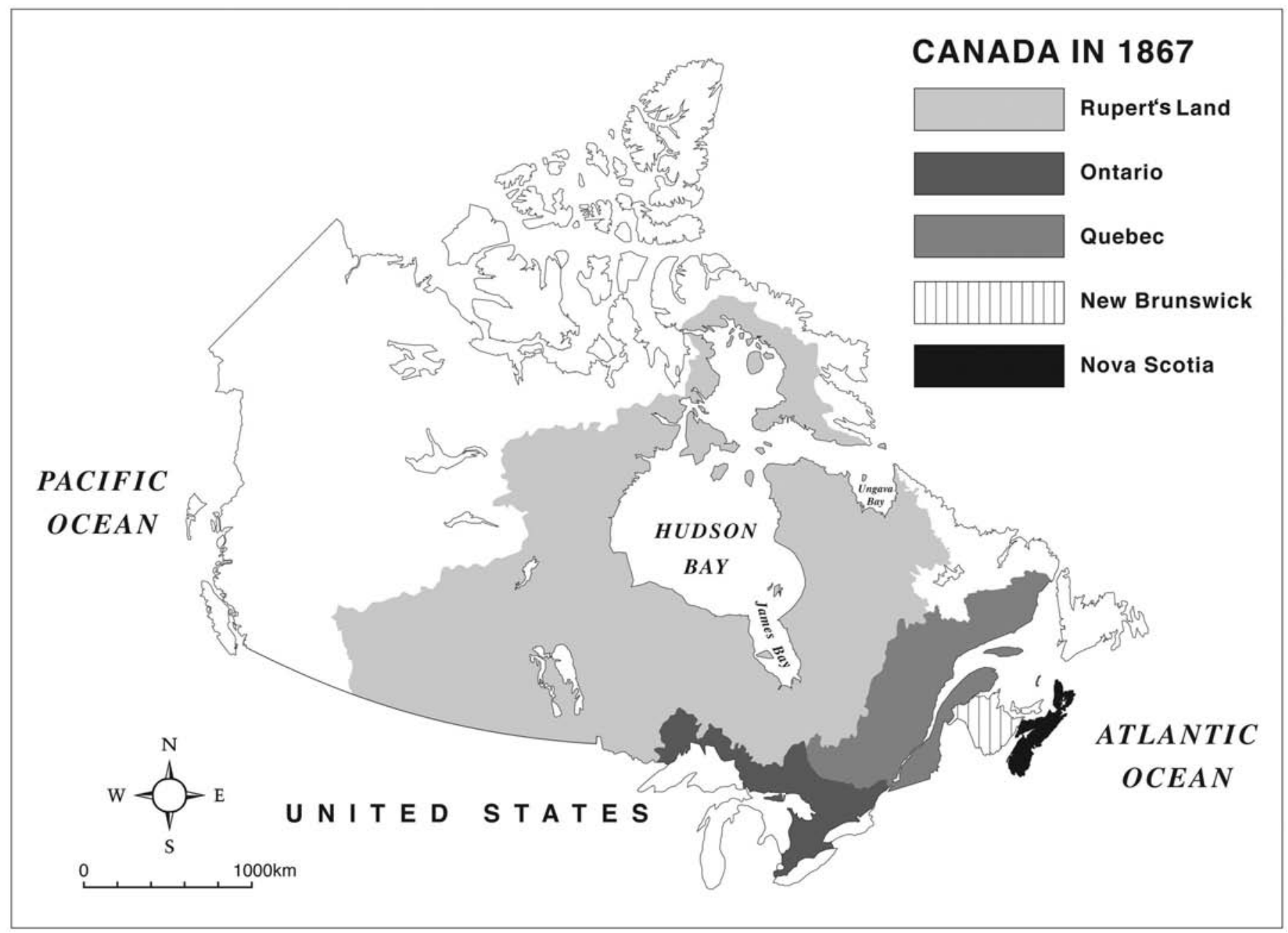

FIG. 1. Canada in 1867 from Tsuji et al. (2009).

ascertained for post-European contact, not pre-European contact. In other words, criterion 2 of the test for Aboriginal title was not fully addressed. In the present paper, Cree Elders share their oral history with respect to Akimiski Island, specific to the time period that corresponds to preEuropean contact, to fully test criterion 2. In addition, we employ state-of-the-art sea-level modelling to time stamp important Cree oral history events.

\section{METHODS}

\section{Study Area}

The western James Bay region of northern Ontario, Canada, is part of the Mushkegowuk Territory and is inhabited by Omushkego Cree who live in four coastal First Nations (Moose Factory, Fort Albany, Kashechewan, and Attawapiskat) and one town, Moosonee (Fig. 4). Place of residence is not static and movement of people between the communities is common. Akimiski Island is located $\sim 16 \mathrm{~km}$ from the mouth of the Attawapiskat River and is the largest island in James Bay (NASA, 1994, 1997; Fig. 4).

\section{Oral History}

Purposive sampling was used in the present study; only Omushkego Cree Elders ( $\geq 60$ years of age) were interviewed unless other knowledgeable community members were identified by personnel of First Nations organizations. Oral historical data were collected from 2007 to 2008, using the semi-directed interview format, which is culturally appropriate (Tsuji et al., 2007). Individual semi-directed interviews $(\mathrm{n}=92 ; 71$ males and 21 females) were conducted in person in either English or Cree, at a location agreed upon by the participant. Oral consent for the interview was given by all participants, and some interviews were recorded (separate oral consent was obtained for this activity). During the semidirected interview, participants were asked to recall any information related to Akimiski Island prior to the arrival of the Europeans (i.e., white man). It should be noted that "high" Cree (cf. conversational Cree that people of the Mushkegowuk Territory often employ) was used by some Elders in recounting their oral history; thus, members of our research team included people proficient in "high" Cree. In addition, interviews with some Elders required 


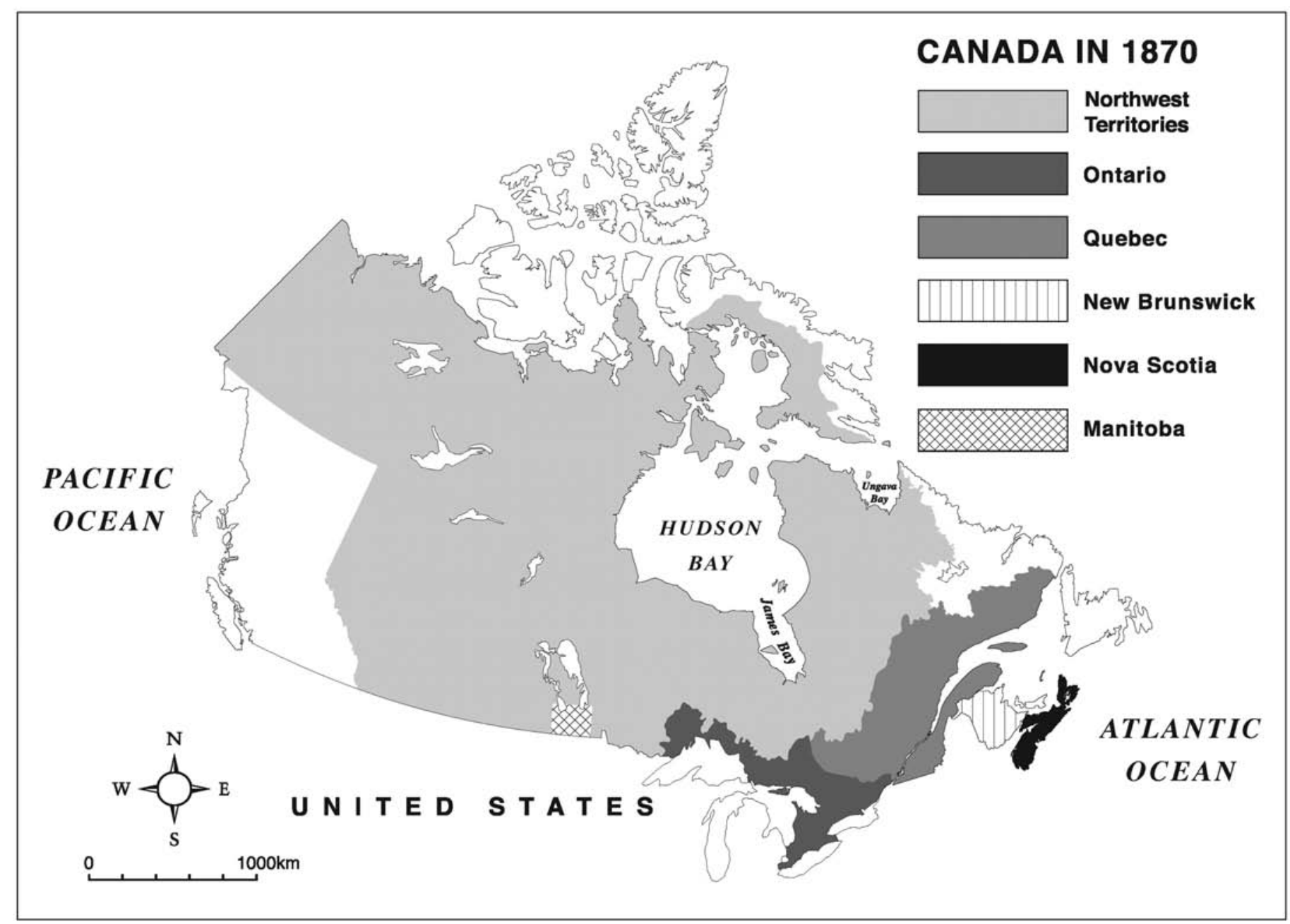

FIG. 2. Canada in 1870 from Tsuji et al. (2009).

more than one session for various reasons (e.g., participants became tired).

Digitally recorded oral history was first transcribed verbatim, and all data were subsequently analyzed and categorized. Categories were created using inductive thematic analyses, whereby categories emerged from the raw data itself (Fereday and Muir-Cochrane, 2006). Data analysis was iterative.

\section{The Emergence of Akimiski Island: Sea-Level Retrodiction}

The evolution of topography and shorelines in the James Bay region is dominated by ongoing variations in sea level driven by the last ice age. Our reconstruction of shoreline changes is based on a state-of-the-art ice age sea-level theory and numerical algorithm that accurately accounts for changes in shoreline geometry and perturbations in Earth rotation (Milne et al., 1999; Kendall et al., 2005; Mitrovica et al., 2005). The theory requires, on input, models for both the ice history since the Last Glacial Maximum ( $\sim 25000$ years before present) and Earth structure.

Below we discuss results based on a slightly modified version of the ICE-6G ice history (Argus et al., 2014;
Peltier et al., 2015) and adopt a 3-D viscoelastic Earth model preferred by Clark et al. (2019) in their study of the Cascadia region. Clark et al. (2019) demonstrated that sealevel predictions based on this specific combination best fit observations of post-glacial decay times in Hudson Bay and James Bay, while simultaneously fitting relative sea-level histories along the Pacific Northwest coast of the United States. Aspects of the adopted Earth model are summarized in Figure 5.

The model is characterized by an elastic lithosphere with a thickness that varies globally (Conrad and LithgowBertelloni, 2006) and includes tectonic plate boundaries. The lithospheric thickness under the Hudson Bay and James Bay region (i.e., cratonic Canada) is in the range of $120-140 \mathrm{~km}$ (Fig. 5A). The construction of the 3-D viscosity field is described in detail in Clark et al. (2019). The spherically averaged (i.e., depth dependent) component of the viscosity field matches the VM5a viscosity profile to which the ICE-6G model is coupled (Argus et al., 2014; Peltier et al., 2015). Beneath the lithosphere, the viscosity field varies by about an order of magnitude in the upper mantle (i.e., above $670 \mathrm{~km}$ depth in the mantle) beneath the Hudson Bay and James Bay region (Fig. 5B-D). Finally, 


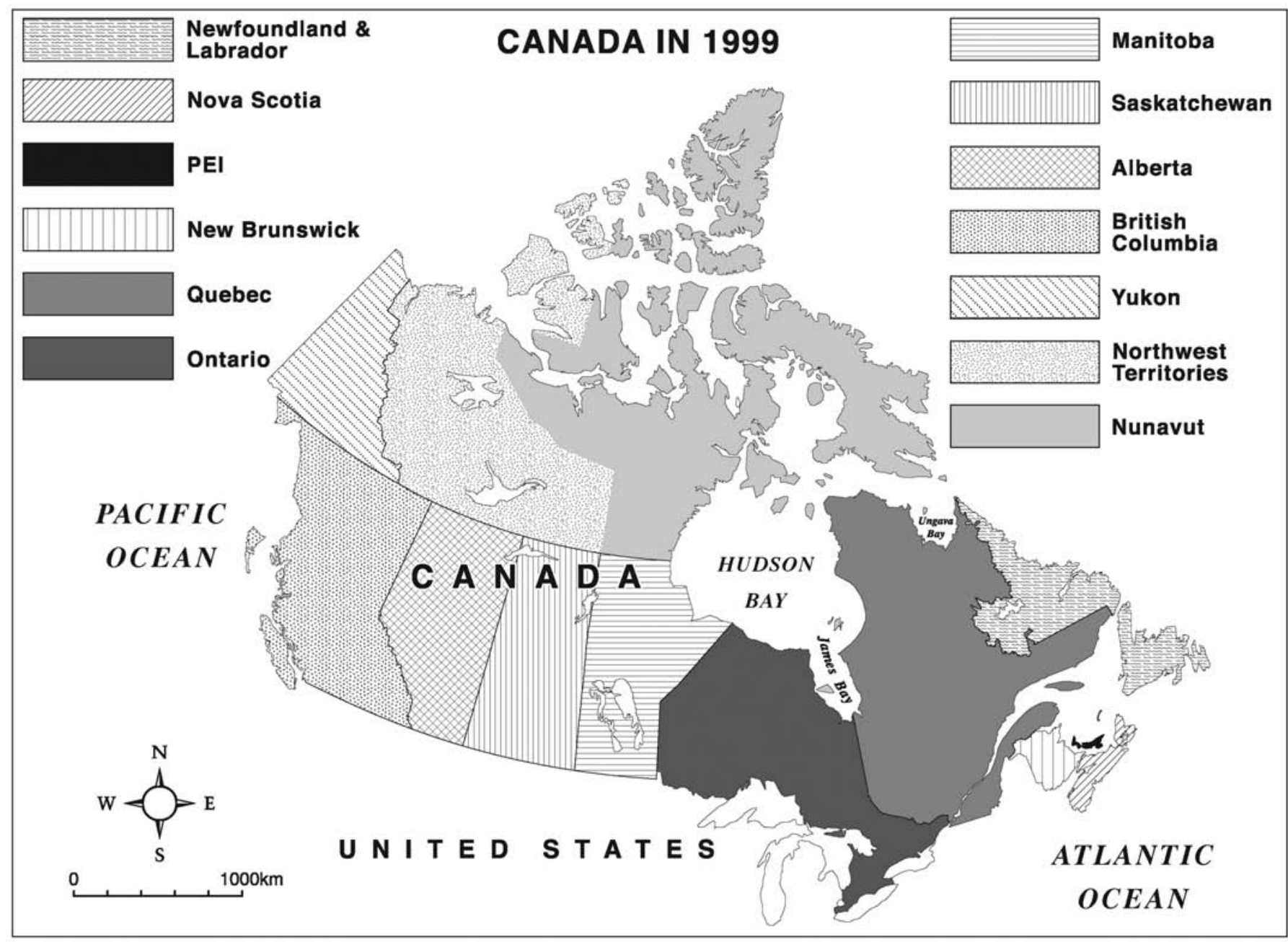

FIG. 3. Canada in 1999 from Tsuji et al. (2009).

we note that the Earth model has a 1-D elastic and density structure given by the seismically inferred model PREM (Dziewonski and Anderson, 1981).

To test the sensitivity of our predictions to variations in the ice history and Earth model, we performed a series of additional simulations in which we varied both these inputs. The results are cited below and described in the Supplement. For all simulations, we scale the entire Laurentide ice history so that predictions of crustal uplift rates based on the model are consistent with the observed rate at the Moosonee site $(9.3 \pm 0.3 \mathrm{~mm} / \mathrm{yr}$; see Tsuji et al., 2016), which was determined by surveying using the Global Positioning System (NRC, 2003). The site is located at the southern tip of James Bay (Fig. 4) and is the closest such site to Akimiski Island. For the simulation described in the main text, the required scaling was 0.86 , and for the simulations summarized in the Supplement, the scaling varied from $0.80-0.89$.

All sea-level calculations are performed using finitevolume software covering a volume that extends from the core-mantle boundary to the Earth's surface (Latychev et al., 2005). The computational domain is discretized using tetrahedral elements with a spatial resolution that varies from $\sim 12 \mathrm{~km}$ at the surface to $\sim 50 \mathrm{~km}$ at the base of the mantle. The numerical algorithm (Kendall et al., 2005) outputs sea-level (and topography) changes from the start of the solution to the present day and involves an iteration that converges to present-day topography. To retrodict past shoreline locations we superimpose the computed changes in sea level onto a present-day topography grid (specified below). Finally, in reconstructing past topography and shoreline changes, we also add a modern global change-induced sea-level rise (associated with recent ice mass flux and thermosteric and dynamic effects) of 1.2 $\mathrm{mm} / \mathrm{yr}$ across the 20th century, following Tsuji et al. (2016), based on a probabilistic analysis of global sea-level changes since 1990 (Hay et al., 2015). We note that varying this rate from $0.0-2.4 \mathrm{~mm} / \mathrm{yr}$ changes the estimated emergence time discussed below by only \pm 10 years.

We reconstruct the topography within James Bay over the past 2500 years using the sea-level methodology described above and a present-day topography grid for the region given by SRTM30 (http://www.webgis.com/srtm30. $\mathrm{html}$ ), which has a spatial resolution of $900 \mathrm{~m}$. Our focus in this application is in estimating the time of emergence of Akimiski Island. The island presently has an area of 


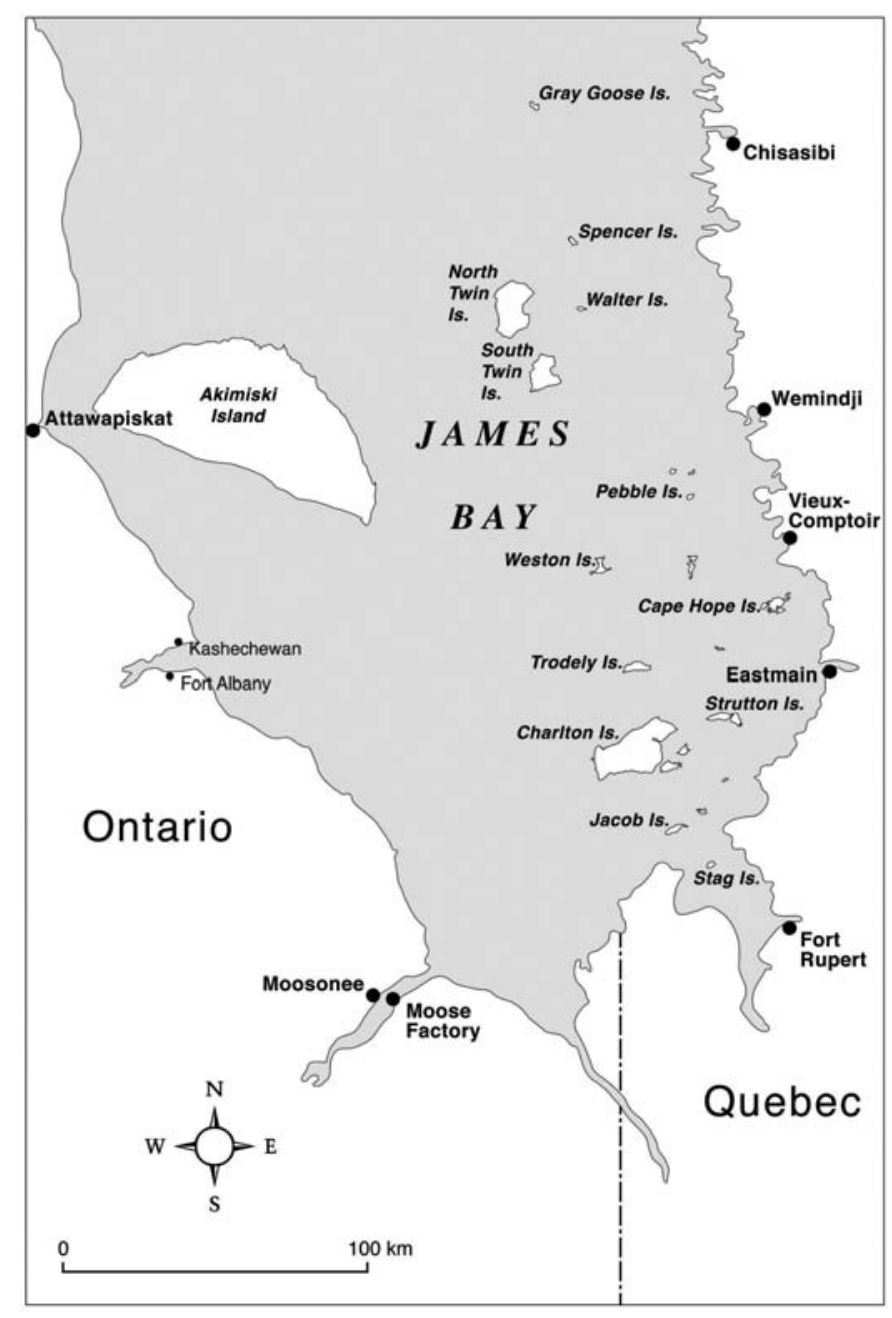

FIG. 4. The location of Akimiski Island in relation to the western James Bay First Nations of Moose Cree (Moose Factory), Fort Albany, Kashechewan, and Attawapiskat, from Tsuji et al. (2009).

$5180 \mathrm{~km}^{2}$ (NASA, 1997), and its western edge lies $\sim 16 \mathrm{~km}$ (NASA, 1994) from the Province of Ontario (Fig. 4 and Fig.6: bottom right).

\section{RESULTS AND DISCUSSION}

\section{Cree Oral History from Interviews}

It should be emphasized that the oral history we requested is limited, as one Elder (interview identifier: sex and participant number, F4) suggested that her Elders would know, and another stated "50 years ago, [we] would have got a lot more information" (M6). The oral history we did record describes Akimiski Island as being bountiful with respect to food:

Before the white man arrived, the island was rich in food, geese, ducks, fish, rabbits.
Families used to live on Akimiski because food was good, geese, ducks, fish, before the white man.

Pre white man. Yes [Cree] hunted there. There was beaver, caribou, rabbit.

These accounts of the bountiful resources of Akimiski Island pre-European arrival converge with the written record of the early post-contact years, as reported by Father Albanel in 1671-72:

Three days' journey into the depth of the [James] bay, toward the Northwest [northern Ontario], is a large river called by some Savages [east-coast Cree] Kichesipiou, and by others Mousousipiou, 'Moose river,' on which are many nations [west-coast Cree]; while on the left, as you advance, lies the well-known Island of Ouabaskou [Akimiski], forty leagues long by twenty wide, abounding in all kinds of animals... On the Island of Ouabaskouk, if the Savages [east-coast Cree] are to be believed, they are so numerous that in one place, where the birds shed their feathers at molting time, any Savages or deer coming to the spot are buried in feathers over their heads, and are often unable to extricate themselves.

(Thwaites, 1959:203-205)

Perhaps the abundance of resources on Akimiski Island at this time is the reason why several of the Elders describe Akimiski Island as being relatively highly populated prior to the arrival of Europeans:

Heard from the Elders [his Elders] that hundreds of Cree lived on Akimiski before the white man. Huge birch bark canoes were used to go across to the island. Hundreds lived on the island, just for survival as there was a lot of fishing, hunting, trapping, and berries. People never got sick.

There is not much I could tell you about Akimiski Island before the white man had arrived here, all I could say that a lot of our people lived there.

Before the paleskin arrived, the island was full of Native families. Guns were never used as there was no steel. Bow and arrows was used to kill game, rabbits, geese, ducks. Fishing was plenty. Beaver was also killed in those days. [There was] berry picking in summer time.

(M1)

One Elder was particularly knowledgeable:

This knowledge has been passed down through the generations. Cree had always used the island as it was 

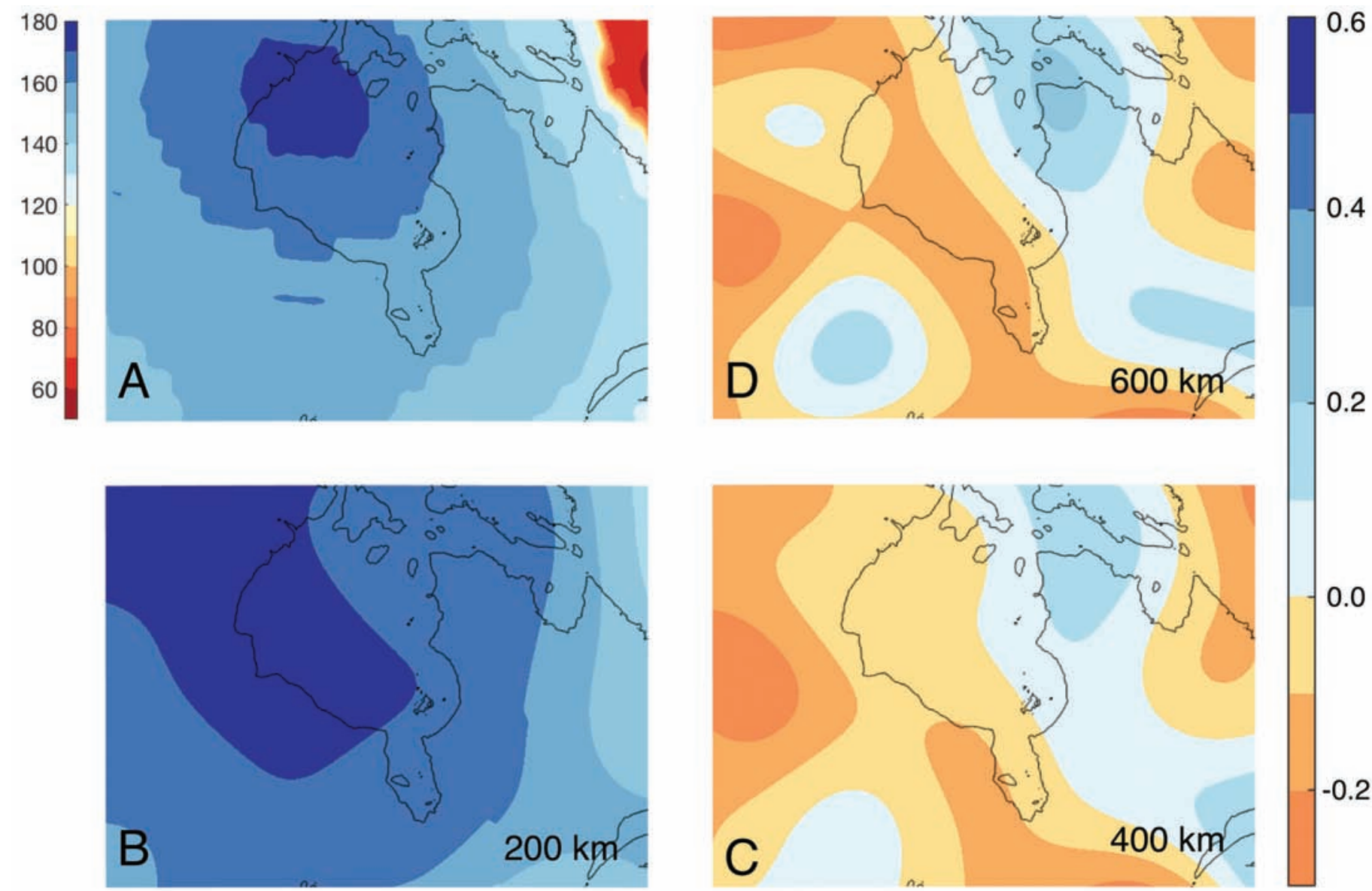

FIG. 5. Aspects of the 3-D viscoelastic Earth model described in the main text. (A) Lithospheric thickness variation (km) across the Hudson Bay and James Bay regions. (B-D) Viscosity variations at three depth slices (as labeled at bottom right). The values on the figure refer to the logarithm of the viscosity variation relative to the 1-D background model, VM5, in the upper mantle $\left(0.5 \times 10^{21} \mathrm{~Pa} \mathrm{~s}\right)$.

plentiful with wild game, game birds, caribou, rabbits, loons. People lived all around the island .... The Cree moved around the island as groups. They used caribou fences where they would herd caribou into a small opening where the hunters would be waiting to shoot [with bows and arrows] the caribou as they came through. [The caribou fence was] funnel-shaped [with] pointed sticks pointing inward so the animals had to follow the fence. Mennikamee [is the] name of fence and place [campsite or hunting ground] on Akimiski.

It is interesting to note that Cree oral history and the post-European record converge on the caribou fence issue, as Lytwyn (2002:84-85) writes that during "spring migration, caribou usually crossed frozen rivers, and the best method of hunting then was to build fences or hedges with snares set in them to trap the animals....did not require European technology, which suggests that caribou could be harvested easily during both spring and fall in the period before European contact." Adding further, Lytwyn (2002:153) notes that, "In the vicinity of Albany Fort [Fort Albany], the caribou hunt was focused on Akimiski Island. The HBC [Hudson's Bay Company] traders at Albany Fort tried on a number of occasions to open up a commercial trade with the lowland Cree hunters on the island ... [in the year] 1727." It should be mentioned that Lytwyn's (2002:xiv) study of the Hudson Bay Lowland Cree (which included the western James Bay Cree) "delved into every corner of the Hudson's Bay Company archives, from account books to miscellaneous files."

Oral history also describes the first contact of Cree living on Akimiski Island with Europeans:

Ship was beached on the north side of the island. The ship stayed awhile because they came on high tide. The white men made a v-ditch in the beach to let the water come in. Four Cree came to investigate and one white man was left on guard, who was [a] cook. The others were making a ditch. [The] white man fired the gun into the air to warn his shipmates; Cree thought that they were shot at.

(M48)

Evidently, Akimiski Island was occupied and used extensively by the Cree prior to European contact according to Cree oral history. This explains the HBC written record that mentions the bountifulness of Akimiski Island with respect to caribou soon after first contact (Lytwyn, 2002). 


\section{Cree Oral History from Published Sources}

Similar to the Cree oral history documented in the present study, Pritchard et al. (2010) report that published Cree oral history indicated that in the past the Inuit did use islands in the western James Bay region, including Akimiski Island, but the period of time was ambiguous:

Atwaywuk [the term], it is supposed to apply to the Inuit people. They came from the Bay[Hudson Bay], because the Ennui [Cree] people used to occupy the land on the West coast of James Bay[.] On the West Coast of Hudson Bay, a place at the junction they call Great Whale River, that's up north and that's occupied by the Inuit people on the shores, and one of the islands on the Belcher Islands in that small islands within James Bay, and the larger island we call Kamanski [sic; Akimiski]. They [Inuit] occupy that land a long time ago, and those people use to hunt seals, whales and polo [sic] bears. So, when they were a long time the Muskego [Cree] also hunt the seals, and that's what the Inuit people hoped for they didn't want the Muskego people to kill off the food, because the Muskego had plenty other kinds inland... The Inuit people that packed [sic, attacked] the Muskego after the European came they killed off some people."

(Bird, 2002:7)

The Cree historian Bird (1999:15 - 16), also recounts a story that he has heard only once:

One time in the James Bay area, because the Inuit people used the in land [sic] which we call, 'akaneskii' [Akimiski] in James Bay and also those small islands. So they used to attack a small group of families and then the whole tribe began to aware of that and they were very annoyed and they said ... 'let us kill off if we can.' And it happens after the European came, because the Omushkegowak [Cree] and also the Inuit did have a gun, not everybody. So when the west coast of James bay people, in a place called Ekwan and Attawapiskat and Kashachewan, they came together and they said, 'lets go attack the Inuit people in the Akimiski Island.' Akimiski Island, Inuit people used to live on the southeast end of the Akimiski Island and some of them to the north end .... Omushkegowak ... gathered the best 100 warriors ... So they said sail right into the end of the southeast coast of the Akimiski Island where the Inuit were camping. So they went there and they killed them off, they wanted to kill them off, all of them ... chase off into the waters these people, women and children and all and they killed them .... Omushkegowak people failed to eliminate totally because of this shaman power [Inuit turned into seals when they entered the water] .... there is another story that says from within the west coast of James Bay ... after they [Cree] clear off the Inuit people [from Akimiski Island], they scare them off into far up north, Inuit people did not stop harassing the Omushkegwak people of the south west coast of Hudson Bay and the west coast of James Bay. They [Cree] usually attack the Inuit people from the Cape Henrietta Maria, where the ice always stuck during the month of June and July and part of August, before it's melt.

As Pritchard et al. (2010) note, the Bird (1999) story diverges from the Hudson's Bay Company Archives, as no mention of Inuit occupation of Akimiski Island or a skirmish between Inuit and Cree over Akimiski Island, post-European contact, appears in the written record of the Hudson's Bay Company Archives (Lytwyn, 2002; HBCA, 1919-41, 1938-40). However, this time discrepancy has been resolved using Cree oral history collected in the present study. Most Elders spoke in general terms of a Cree-Inuit conflict over the Government of Canada's plan in the 1950 s to relocate Inuit to Akimiski Island, with the Inuit ultimately rejecting the relocation plan because the environment was not to their liking (i.e., treed) (F16, M42, M58, M60, M69). However, one Elder was detailed in his account:

HBC [Hudson's Bay Company] wanted Inuit on Akimiski [Island]. Something to do with the beaver, so that the Inuit could bring beaver and replenish the beaver as a harvest on the island .... Indian people in Attawapiskat heard that this was going to happen. [The Cree] had guns and would defend their land and kill the Inuit if they came. [Canadian] Indian Affairs heard and gave support to the Cree. HBC did go through with their [beaver] plan [but did not include the Inuit].

(M48)

There is convergence in the written record on this point, as Cummins (1992:274) relates how an Inuit population was being considered for relocation to Akimiski Island, but in the end the Inuit were not relocated:

A memorandum from V. M. Gran (Superintendent, James Bay Agency) to the Regional Supervisor, North Bay, dated July 5, 1962, states that "Mr. Jock Fyffe of Northern Affairs...was attempting to get possession of [Akimiski] for relocation of Eskimo people." The point of his (Mr. Gran's) letter was to inform the Regional Supervisor that the necessary action was being taken to insure "that [Akimiski would be] retained for Indian trapping."

(Cummins, 1992:274)

\section{Post-Glacial Isostati Adjustment}

Cree oral history also addresses the evolution of Akimiski Island:

No island [at first], just a sandbar. 
Skeleton of a whale when island just starting to form, [the island was made of] gravel [back then]. South side of the island, one of the old stories, named south side story, Whale Point.

It should be emphasized that Cree oral history highlights that the shorelines of the western James Bay region have been continuously evolving due to post-glacial isostatic adjustment (McDonald et al., 1997). Indeed, the Earth has gone through ice-age cycles and at the so-called last glacial maximum, the ancient Laurentide ice sheet covered Canada and the northeastern U.S. (Tsuji et al., 2009). Simplistically speaking, when the Laurentide ice sheet receded, the unloading associated with the melting of the ice sheet initiated an adjustment or rebound of the crust in the James Bay region that is locally evident as land emergence (or sea-level fall). Adding further, Martini and Glooschenko (1984:244) suggest that "Akimiski Island was totally submerged 7500 years ago by the early-postglacial Tyrrell sea [the forerunner of Hudson Bay and James Bay; Dean, 1994] ... emersion may have been initiated approximately 3500-4000 yrs ago." Taking into account that the Indigenous peoples' archeological history in the western James Bay region goes back approximately 6000 years (Woodland Heritage Northwest, 2004), the ancestors of the Cree would have been in the area to witness the emergence of Akimiski Island, with this information becoming part of their oral history.

The evolution of Akimiski Island is of primary importance to the objective of the present paper, as evident from the following oral history:

Inuit at Akimiski Island first, but not know what year. Legend tells about how Akimiski Island started as a sandbar and Inuit would come to hunt seals. Once there were trees [on Akimiski Island], there were no more seals and the Inuit stopped coming. Cree also battled with the Inuit and drove them off. The Inuit never came back.

Alright, it's about Agamiski [sic], what my dad told me, two months ago [before he passed away]. Before white man came ... first there were Eskimos there he said, there were small trees, just a sandbar, then Eskimos ... were there because there was lots of seals. They like them seals, them Eskimos. That's what my dad said, and then after lots of years I guess there were trees, big ones. It's about a seven, eight miles long now that I know. When there were trees there were no more seals. The Eskimos and Cree fought, the Eskimos left and went home.

In Voices from the Bay (McDonald et al., 1997) - a compilation of Inuit and Cree cultural knowledge for the
Hudson and James Bay regions, where 28 communities participated including the western Hudson Bay Cree community of Peawanuck and the western James Bay Cree communities of Attawapiskat, Kashechewan, Fort Albany, and Moose Factory, as well as the most southerly Inuit community in Hudson Bay, Sanikiluaq-similar stories were recorded, although not specific to Akimiski Island and not specific to seals:

Rocks are exposed on sandy beaches and shallow areas are now shoals. Shoals are forming new islands near Arviat, York Factory, Peawanuck, Lake River, Moose Factory, Wemindj, and in the Belcher Islands .... Emerging shorelines are very obvious in James Bay and along the southwestern coast of Hudson Bay where shoals have risen above sea level .... Large rocks and sandbars are now visible, and as an island in southwestern Hudson Bay slowly merges with the shorelines fewer walrus are visiting it .... A decline in local walrus numbers observed by James Bay and southwestern Hudson Bay Cree is associated with changing shorelines and habitat alteration. Walrus used to inhabit Cape Hope Island, but the depressions they made in the ground are now overgrown with willow. Lots of walrus also inhabited an island in the Winisk area until it began merging with the coastal shoreline in the early $1980 \mathrm{~s}$. Now they return only to visit, in groups of two or three.

(McDonald et al., 1997:37-42)

According to Cree oral history, the Inuit used Akimiski Island to hunt seals when the island was first emerging. However, the Inuit later abandoned the island because the number of seals at the island decreased, either because of the evolution of the island habitat, the Cree forcing them off the island, or both. What is unknown is the timing of the emergence of Akimiski Island. Of importance for the Cree to satisfy criterion 2 of the test for Aboriginal title, Cree traditional use and occupancy of Akimiski Island needs to be established prior to the 1600s (General et al., 2017), the time of assertion of sovereignty by European nations (INAC, 1993, 2003).

The emergence of Akimiski Island was estimated using sea-level retrodiction. Figure 6 shows a simulation of changes in topography and shoreline location in James Bay for six time slices extending back to $2.5 \mathrm{ka}$. Areas in shades of blue on each frame are water covered. As we noted previously, the region is currently experiencing a sea-level fall at a rate of $\sim 1 \mathrm{~cm} / \mathrm{yr}$ and thus land has been progressively emerging since the area became ice-free during the Early Holocene. On the basis of this simulation, we estimate that Akimiski Island first emerged from James Bay at 2030 years ago (see Fig. 6, top middle, southern coast) and reached $\sim 50 \%$ of its current areal extent 1000 years ago. The sensitivity study described in the Supplement yielded nine additional estimates of the emergence time based on simulations that varied both the ice history and the 


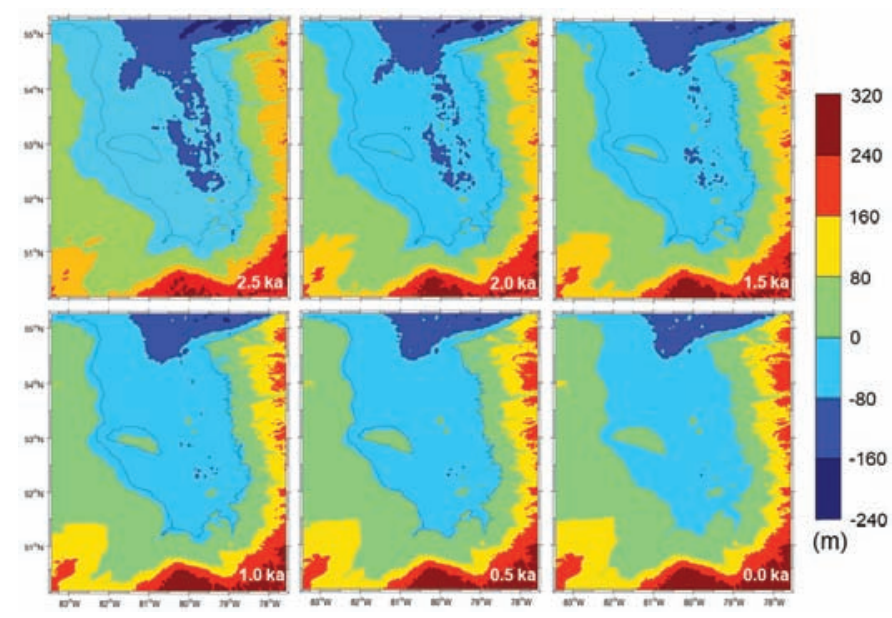

FIG. 6. Topography in the James Bay region for six before present time slices spanning the period from 2500 years ago $(2.5 \mathrm{ka})$ to present-day $(0.0 \mathrm{ka})$, as labelled on each frame. The snapshots of paleotopography are reconstructed as described in the text. Present-day $(0.0 \mathrm{ka})$ shorelines are presented as dotted lines in the time slices. Prediction is based on the 3-D Earth model described in the main text (Simulation 1 of the Supplement).

Earth model, and these suggest an emergence time of 2000 \pm 100 years. In addition, the material in the Supplement demonstrates that relative sea level (RSL) histories predicted by all $103-\mathrm{D}$ models is consistent with observations from the western James Bay region.

\section{CONCLUSION}

Clearly, Cree traditional use and occupancy of Akimiski Island was "sufficient to be an established fact at the time of assertion of sovereignty by European nations" (INAC, 1993:5, 2003:8); thus, fully addressing criterion 2 of the test for Aboriginal title. Indeed, our sea-level retrodiction has time stamped the Cree oral history of the emergence of Akimiski Island to $2000 \pm 100$ years ago, and the Inuit leaving Akimiski Island to the time period 2.0 to $1.5 \mathrm{ka}$. Five hundred years (i.e., 2.0 to $1.5 \mathrm{ka}$ ) would be sufficient time for an emergent sandbar (i.e., seal habitat) to evolve into boreal forest (see Martini and Glooschenko, 1984, for a detailed description of emergent coasts of Akimiski Island). As the Cree have addressed all the criteria of the common-law test for proof of Aboriginal title with respect to Akimiski Island (General et al., 2017 and the present study) while, the Inuit have not (Pritchard et al., 2010), the Cree have sufficient basis to enter into the Recognition and Implementation of Indigenous Rights process. This new process replaces the Comprehensive Land Claims policy (Crown-Indigenous Relations and Northern Affairs Canada, 2018, 2019).

Akimiski Island is important for social and cultural reasons: the Cree continue to hunt, fish, trap, and gather (e.g., berries, medicinal plants, wood) on the island, and the island is dotted with graves, spiritual sites, and Cree seasonal camps (Tsuji et al., 2011; General et al., 2017). In addition, the mineral wealth of the Far North region of
Ontario is well documented (Gamble, 2017; Ministry of Northern Development and Mines, 2019; Northern Ontario Business, 2020). Indeed, Akimiski Island has already been prospected for diamonds (Tsuji et al., 2009); thus, land rights have substantial economic implications for the First Nations people of this region (Tsuji et al., 2016).

It is unfortunate that the Government of Canada does not follow its own policy with respect to the common-law test for proof of Aboriginal title when settling comprehensive land claims, and puts the onus of responsibility of proving Aboriginal title on groups who have limited financial resources. As noted by Senator Lorna Milne of the Government of Canada:

many of the complaints [boundary and Aboriginal title issues related to Akimiski Island] were originally with the Nunavut Act itself. That is when they should properly have been addressed. Unfortunately, they were not addressed at that time. You [First Nations representatives] are quite right: the [Canadian] government did not do its job.

(Parliament of Canada, 1999:33)

Lastly, the word Akamaski [Akimiski] is derived from Cree words-Aka (across) and Aski (land) - that is, "saying that there is land across here" (M48).

\section{ACKNOWLEDGEMENTS}

We thank all the Elders who participated, and all other community members who helped with this project including translators, especially Ruby Edwards-Wheesk, Ralphael Wheesk, Leonard Edwards, Laurette Edwards, Roger Davey, and Alex Stephens. We also thank the Social Sciences and Humanities Research Council of Canada, the Canadian Institutes of Health Research, and the Harvard University Climate Change Solutions Fund for funding support.

\section{REFERENCES}

AANDC (Aboriginal Affairs and Northern Development Canada; now Crown-Indigenous Relations and Northern Affairs Canada). 2019. Pre-1975 Treaties.

https://www.aadnc-aandc.gc.ca/DAM/DAM-INTERHQ-AI/STAGING/texte-text/mprm_treaties_th-ht_ canada_1371839430039_eng.pdf

Argus, D.F., Peltier, W.R., Drummond, R., and Moore, A.W. 2014. The Antarctica component of postglacial rebound model ICE6G_C (VM5a) based on GPS positioning, exposure age dating of ice thicknesses, and relative sea level histories, Geophysical Journal International 198(1):537-563. https://doi.org/10.1093/gji/ggu140 
Bird, L. 1999. 0107-Our Voices-Shamanism (cultural story). Bird Number: 2. Recorder: Louis Bird. Date Recorded: December 8, 1999. Transcriber: Mark F. Rumi. Date Transcribed: 2000. Language: English. Culture: Cree (Omushkego). Transcript: Proof. http://www.ourvoices.ca/filestore/pdf/0/1/0/7/0107.pdf

—__ 2002. 0108-Our Voices-Shamanism. Bird Number: 2052. Recorder: Louis Bird. Transcriber: Kathy Mallett. Date Transcribed: December 2002. Language: English. Culture: Cree (Omushkego). Transcript: Draft. http://www.ourvoices.ca/filestore/pdf/0/1/0/8/0108.pdf

Cauchon, J., and Cockburn, J. 1867. Rupert's Land and NorthWestern Territory - Enactment No. 3. Schedule (A). https:/www.justice.gc.ca/eng/rp-pr/csj-sjc/constitution/ lawreg-loireg/p1t31.html

Clark, J., Mitrovica, J.X., and Latychev, K. 2019. Glacial isostatic adjustment in central Cascadia: Insights from threedimensional Earth modeling. Geology 47(4):295-298. https://doi.org/10.1130/G45566.1

Conrad, C.P., and Lithgow-Bertelloni, C. 2006. Influence of continental roots and asthenosphere on plate-mantle coupling. Geophysical Research Letters 33(5), L05312. https://doi.org/10.1029/2005GL025621

Crown-Indigenous Relations and Northern Affairs Canada. 2018. Overview of a recognition and implementation of Indigenous rights framework. Ottawa, Ontario: CIRNAC.

https://www.rcaanc-cirnac.gc.ca/eng/1536350959665/ 1539959903708

___ 2019. About recognition of Indigenous rights and selfdetermination discussion tables. Ottawa, Ontario: CIRNAC. https://www.rcaanc-cirnac.gc.ca/eng/1511969222951/1529103 469169\#chp7

Cummins, D.B. 1992. Attawapiskat Cree: Land tenure and use 1901-1989. PhD thesis, McMaster University, Hamilton, Ontario.

Dean W.G. 1994. The Ontario landscape, circa A.D. 1600. In: Rogers, E.S., and Smith, D.B., eds. Aboriginal Ontario: Historical perspectives on the First Nations. Toronto, Ontario: Dundurn Press Ltd. 3-20.

Delgamuukw v. British Columbia. 1997. Supreme Court judgments: 3 SCR 1010. Case No. 23799.

https://scc-csc.lexum.com/scc-csc/scc-csc/en/item/1569/index. do

Denhez, M. 1982. Aboriginal rights and the sovereignty of countries (including a case study of the Canadian Arctic). https://www.cwis.org/wp-content/uploads/documents/ statsovr.txt

Dziewonski, A.M., and Anderson, D.L. 1981. Preliminary reference Earth model. Physics of the Earth and Planetary Interiors 25(4):297-356. https://doi.org/10.1016/0031-9201(81)90046-7

Fereday, J., and Muir-Cochrane, E. 2006. Demonstrating rigor using thematic analysis: A hybrid approach of inductive and deductive coding and theme development. International Journal of Qualitative Methods 5(1):80-92.

https://doi.org/10.1177/160940690600500107
Gamble, J. 2017. What's at stake in Ontario's Ring of Fire. Canadian Geographic March/April.

https://www.canadiangeographic.ca/article/whats-stakeontarios-ring-fire

General, Z., Tsuji, S.R.J., and Tsuji, L.J.S. 2017. Akimiski Island, Nunavut, Canada: An island in dispute. Canadian Journal of Native Studies 37(2):1-25.

HBCA (Hudson's Bay Company Archives). 1919-41. Attawapiskat Post, Post Journals B.243/a/1-5, B.241/a/5-7. Winnipeg, Manitoba: Hudson's Bay Company Archives, Archives of Manitoba.

- 1938-40. Belcher Islands Post, Post Journals, B.388/a. Winnipeg, Manitoba: Hudson's Bay Company Archives, Archives of Manitoba.

Hay, C.C., Morrow, E., Kopp, R.E., and Mitrovica, J.X. 2015. Probabilistic reanalysis of 20 th century sea-level rise. Nature 517:481-484.

https://doi.org/10.1038/nature14093

Hurley, M.C. 2000. Aboriginal title: The Supreme Court of Canada decision in Delgamuukw v. British Columbia. Background Paper, BP-459E. Ottawa, Ontario: Library of Parliament, Parliamentary Research Branch.

INAC (Indigenous and Northern Affairs Canada). 1993. Federal policy for the settlement of Native claims. Ottawa, Ontario: INAC. $31 \mathrm{p}$.

2003. Resolving Aboriginal claims: A practical guide to Canadian experiences. Ottawa, Ontario: INAC. 46 p. https://www.aadnc-aandc.gc.ca/eng/1100100014174/110010001 4179

- 2016. $250^{\text {th }}$ anniversary of the Royal Proclamation of 1763. Ottawa, Ontario: INAC (now Crown-Indigenous Relations and Northern Affairs Canada).

https://www.aadnc-aandc.gc.ca/eng/1370355181092/ 1370355203645

Kendall, R.A., Mitrovica, J.X., and Milne, G.A. 2005. On postglacial sea level - II. Numerical formulation and comparative results on spherically symmetric models. Geophysical Journal International 161(3):679-706. https://doi.org/10.1111/j.1365-246X.2005.02553.x

Latychev, K., Mitrovica, J.X., Tromp, J., Tamisiea, M.E., Komatitsch, D., and Christara, C.C. 2005. Glacial isostatic adjustment on 3-D Earth models: A finite-volume formulation. Geophysical Journal International 161(2):421 - 444. https://doi.org/10.1111/j.1365-246X.2005.02536.x

Lytwyn, V.P. 2002. Muskekowuck Athinuwick: Original people of the great swampy land. Winnipeg: University of Manitoba Press. 289 p.

Martini, I.P., and Glooschenko, W.A. 1984. Emergent coasts of Akimiski Island, James Bay, Northwestern Territories, Canada: Geology, geomorphology, and vegetation. Sedimentary Geology 37(4):229-250. https://doi.org/10.1016/0037-0738(84)90016-2

McDonald, M., Arragutainaq, L., and Novalinga, Z. 1997. Voices from the Bay: Traditional ecological knowledge of Inuit and Cree in the Hudson Bay bioregion. Ottawa, Ontario: Canadian Arctic Resources Committee. 98 p. 
Milne, G.A., Mitrovica, J.X., and Davis, J.L. 1999. Near-field hydro-isostasy: The implementation of a revised sea-level equation. Geophysical Journal International 139(2):464-482. https://doi.org/10.1046/j.1365-246x.1999.00971.x

Milton Freeman Research Limited. 1976. Inuit land use and occupancy project, 3 vols. Ottawa, Ontario: Minister of Supply and Services Canada.

Ministry of Energy, Northern Development and Mines. 2019. Ring of fire. Toronto: Government of Ontario. https://www.mndm.gov.on.ca/en/ring-fire

Mitrovica, J.X., Wahr, J., Matsuyama, I., and Paulson, A. 2005. The rotational stability of an ice-age Earth. Geophysical Journal International 161(2):491-506. https://doi.org/10.1111/j.1365-246X.2005.02609.x

NASA (National Aeronautics and Space Administration). 1994. NASA Photo ID: STS066-121-27. https://eol.jsc.nasa.gov/SearchPhotos/photo.pl?mission=STS0 $66 \&$ roll $=121 \&$ frame $=27$

___ 1997. NASA Photo ID: STS085-713-70.

https://eol.jsc.nasa.gov/SearchPhotos/photo.pl?mission=STS0 $85 \&$ roll $=713 \&$ frame $=70$

Northern Ontario Business. 2020. Ontario, First Nations agree on missing link road to the Ring of Fire, March 2.

https://www.northernontariobusiness.com/regional-news/farnorth-ring-of-fire/ontario-first-nations-agree-on-missing-linkroad-to-the-ring-of-fire-2132065

NRC (Natural Resources Canada). 2003. Passive control networks: Canadian Base Network. Ottawa, Ontario: NRC.

https://webapp.geod.nrcan.gc.ca/geod/data-donnees/passivepassif.php? network $=$ cbn\&locale $=$ en

Nunavut Act. 1993. Nunavut Act S.C. 1993, c. 28. Canadian Legal Information Institute (Federation of Law Societies of Canada) Ottawa, Ontario: Consolidated Statutes of Canada. http://canlii.ca/t/5431p

Nunavut Land Claims Agreement. 1993. Agreement between the Inuit of the Nunavut Settlement Area and Her Majesty the Queen in Right of Canada. Ottawa, Ontario: Minister of Indian Affairs and Northern Development and the Tungavik Federation of Nunavut. 282 p.

https://www.gov.nu.ca/sites/default/files/Nunavut_Land_ Claims_Agreement.pdf

Parliament of Canada. 1999. Proceedings of the Standing Senate Committee on Legal and Constitutional Affairs: Issue 54 Evidence.

http://www.parl.gc.ca/36/1/parlbus/commbus/senate/com-e/ lega-e $/ 54 \mathrm{ev}$-e.htm? Language $=\mathrm{E} \& \mathrm{Parl}=36 \& \mathrm{Ses}=1 \& \mathrm{comm}$ id $=11$

Peltier, W.R., Argus, D.F., and Drummond, R. 2015. Space geodesy constrains ice age terminal deglaciation: The global ICE-6G_C (VM5a) model. Journal of Geophysical Research Solid Earth 120(1):450-487. https://doi.org/10.1002/2014JB011176
Pritchard, C., Sistili, B., General, Z., Whitelaw, G.S., McCarthy, D.D., and Tsuji, L.J.S. 2010. Akimiski Island, Nunavut, Canada: A test of Inuit title. Canadian Journal of Native Studies 30(2):407-414.

Rupert's Land and North-Western Territory - Enactment No. 3. 1870. Part 1. Order of Her Majesty in Council admitting Rupert's Land and the North-Western Territory into the union, dated the $23^{\text {rd }}$ day of June 1870.

https://www.justice.gc.ca/eng/rp-pr/csj-sjc/constitution/ lawreg-loireg/p1t31.html

Thwaites, R.G., ed. 1959 [1899]. The Jesuit Relations and allied documents: Travels and explorations of the Jesuit missionaries in New France 1610-1791. Vol. LVI: Lower Canada, Iroquois, Ottawas, Hudson Bay: 1671-1672. New York: Pageant Book Co.

http://moses.creighton.edu/kripke/jesuitrelations/relations 56. html

Treaty No. 9. 1905-06. The James Bay Treaty. Treaty No. 9 (made in 1905 and 1906) and adhesions made in 1929 and 1930. https:/www.rcaanc-cirnac.gc.ca/eng/1100100028863/1581293 189896\#chp1

Tsilhqot'in Nation v. British Columbia. 2014. Supreme Court judgments: SCC 44. Report 2 SCR 257. Case No. 34986.

https://scc-csc.lexum.com/scc-csc/scc-csc/en/item/14246/ index.do

Tsuji, L.J.S., Manson, H., Wainman, B.C., Vanspronsen, E.P., Shecapio-Blacksmith, J., and Rabbitskin, T. 2007. Identifying potential receptors and routes of contaminant exposure in the traditional territory of the Ouje-Bougoumou Cree: Land use and a geographical information system. Environmental Monitoring and Assessment 127:293-306.

https://doi.org/10.1007/s10661-006-9280-Z

Tsuji, L.J.S., Gomez, N., Mitrovica, J.X., and Kendall, R. 2009. Post-glacial isostatic adjustment and global warming in subarctic Canada: Implications for islands of the James Bay region. Arctic 62(4):458-467.

https://doi.org/10.14430/arctic176

Tsuji, L.J.S., McCarthy, D.D., Whitelaw, G.S., and McEachren, J. 2011. Getting back to basics: The Victor Diamond Mine environmental assessment scoping process and the issue of family-based traditional lands versus registered traplines. Impact Assessment and Project Appraisal 29(1):37-47.

https://doi.org/10.3152/146155111X12913679730755

Tsuji, L.J.S., Daradich, A., Gomez, N., Hay, C., and Mitrovica, J.X. 2016. Sea level change in the western James Bay region of subarctic Ontario: Emergent land and implications for Treaty No. 9. Arctic 69(1):99-107.

https://doi.org/10.14430/arctic4542

Woodland Heritage Northwest. 2004. Stage one and two project report archeological/cultural heritage potential site assessment for southwest alternative winter road right of ways from Hearst northerly approximately $320 \mathrm{~km}$ to the Victor diamond project site. 134 College Street, Thunder Bay, Ontario: Woodland Heritage Northwest. 